Volume 7 Issue 2, June 2020

Nationally Accredited Journal,

Decree No. B/4130/E5/E5.2.1/2019

\title{
Implementation of Legal Protection of Confidential obligation Notary In Running Position
}

\author{
Djuniatno Hasan ${ }^{1}$, Agus Ekhsan ${ }^{2}$ and Gunarto ${ }^{3}$
}

Abstract. This research aims to: 1)To know and understand, that notaries who runs the office for public use, in addition to protection by the State, as well as the protection of Indonesian Notary Association and Honorary Council of Notaries; 2) Assess and analyze about a Notary that in using the rights and obligations dissenter contained in the Law on Notary, and legislation more specifically and expressly provides that the Notary concerned shall provide information, and in this case when the Notary the unlock the secrets of (the contents of) the deed; 3)To assess, and to know what are the weaknesses, as well as a solution to the problems in the implementation of legal protection in carrying secret notary office as a notary public.

Type of this research is by using a normative juridical approach of the Act (statute approach), Conceptual approach. Legal materials used are the primary law materials, secondary law, and the tertiary law.

Based of this study concluded that: 1) Under the provisions of Act No. 2 of 2014, amendments to the Act No. 30 of 2004 Article 4 and Article 16 paragraph (1) letter $\mathrm{f}$, that Notaries have the authority and obligation to keep professional secrecy regarding the Deed and any information obtained in the manufacture of deed and conceal the contents of the deed and he knew a good description of the past, present and future; 2) that the Notary is obliged and has a right of refusal on the confidentiality deed that has been made and all information obtained for a deed in accordance with the oath / pledge of office, unless the law determines the other; and 3) Based on the description of the foregoing in the implementation of the legal protection of notary there are still weaknesses in terms of both implementation and legal certainty. Hope writer immediately formed a legislation or regulation, regulate the enforcement of justice, as well as agencies or other legal institutions.

Keywords: Notary; Rights and Obligations of Ingratitude Secrets Office.

\section{Introduction}

Indonesia is said to be a state of law has been stated in the explanation of Law - the Constitution of 1945. In the explanation of the system of government, saying that, "Indonesia is a state based on law (Rechtsstaat), not based on power alone (machtsstaat)". Then reinforced. Article 1, paragraph 3 amendment - $3^{4}$ :"Explaining that the Indonesian state power is run through the applicable law in Indonesia. all aspects of life is set up through legitimate law so as to prevent conflicts among citizens". State law is a common type of state which is owned by the nation - a nation in the world today. Because of this law is the limit that the authorities in order not act arbitrarily - treatment in running the country.

According to Indonesian law system, organs and / or tools fixtures State has the obligation give service to the community include: Institutions Justice by the court and its officials as a judge or panel of judges, namely: Organs of State that provides legal

\footnotetext{
${ }^{1}$ Student Master of Notary Program, email: junnotaris@82gmail.com

2 Student of Master of Law Program, Faculty of Law, Universitas Islam Sultan Agung email xsanums@gmail.com

3 Faculty of Law, Universitas Islam Sultan Agung

${ }^{4}$ General Explanation of the 1945 Constitution, on the System of the State Government, Article 1, paragraph 3, Amendment 3
} 
services to people who are looking for justice. With regard to the matters or disputes which have been encountered, which is where the solution requires a court decision. Service to the community in the field of justice is granted by the state specifically that according to the case can be made under civil law, criminal law, administrative law state, customary law and religious law on the side of that there are several government agencies with government officials / executives, the state organs which provide public services under the laws of another state organ public. and make a note of legitimate and credible and will be used as proof that a strong and independent nature, as well as the notary does not favor one party and protect the interests of members of the public who request their services, keep the contents of the deed which was made in front of him, So, General Officer in this case the notary must government to provide legal protection up to the notary that the field work in the field of private law are public, because the scope of work is very broad and complex, have a duty and responsibility is very heavy, to realize the aims and objectives of the parties Authentic wills deed as evidence is good, true and not flawed. Pursuant to Article 16 paragraph (1) of Act No. 2 of 2014 Constitution of the Notary Amendment (UUJN-P) revisions to the Act. Regulation No. 30 of 2004 Notary (PJN) concerning Notary, in performing his compulsory notarial act trustworthy, honest, thorough, independent, impartial, and safeguard the interests of those involved in the legal act $^{5}$. Indeed, in the same chapter there is an obligation to keep secret notary deed regarding the content they make, but this obligation is excluded if the law decides otherwise. However, if the parties concerned have recourse to the Notary, odds are still something to do with the deed that has been made, so in this case the manufacturer deed must also be involved, whether as witnesses, expert witnesses, or it could be a defendant in some of the parties concerned related with a product certificate that has been made, in addition to the notary as related parties could be required to notify the contents (Open Secrets) of the deed. In general, the notary a deed can be called by the investigator (cq Police / police), or the Public Prosecutor (cq Attorney) as a witness to how far the consequences or responsibilities in the context of the examination Notary allowed to tell the investigator or the public prosecutor and how, if the Notary is not willing to inform the content or the background of a deed which is understood to investigator or prosecutor.

Notary right of refusal granted by the Act is not only a due, but an obligation, so that the notary is obliged to not speak, once in court. Even though the notary by his client was given permission to speak, still can use his broken Rights, because the obligation to keep confidential and not put the situation by the client, but by the Act. In determining how far the reach of right of refusal of the notary should start from liability for the notary, not to talk about that is listed in the deed as well as regarding communicated to him because of his position, except in case there is the benefit of a higher or in matters that to the notary by a legislation in force, can it expressly exempted from secret oath of office ${ }^{6}$.

Under the Right to reject notary symposium organized by the Commissariat Notary Association East Java on December 11,1982, right of refusal notary is not just a right but also an obligation. because if violated, there will be sanctions ${ }^{7}$. Based on the background of the problems described above, it can be formulated the problem as follows: First: How is the implementation of legal protection for a notary in carrying out obligations official secret, Second: Do Notaries can use the Rights and Duties of Dissenters in accordance to

\footnotetext{
${ }^{5}$ Article 16 figure 1a Act On Notary (UUJN No. 2 of 2014)

6 Ngadino, 2019 Tugas dan tanggung jawab jabatan notaris di indonesia.UPT penerbitan universitas PGRI Op, Cit, p. 120

${ }^{7}$ A. Kohar, 1984, Hak Ingkar Notaris Dimposiumkan, tulisan dalam Notaris berkomunikasi, penerbit Alumni, Bandung p. 157
} 
Volume 7 Issue 2, June 2020

Nationally Accredited Journal,

Decree No. B/4130/E5/E5.2.1/2019

Law Notary, and Do notary allowed to open Content (secret) Deed in front of the investigator and prosecutor, Third: Does weakness, and solution implementation notary legal protection in carrying out professional secrecy obligations.

\section{Research methods}

This study is a descriptive analysis that outlines the facts to gain an overall picture of the Notary obligation to keep secret the contents of (confidential) deed, right of refusal and legal protection against notaries who open the contents of (secret) of his deed. This study uses normative legal research methods, namely the collection of data through such a normative approach that prioritizes search library materials secondary data with primary legal materials, secondary and tertiary. Collecting data this study conducted library research (library research).

\section{Results And Discussion}

\subsection{Legal Protection Of Notary In Running For Secret Service Obligations}

Judging from the theoretical aspects and judicial practice in running his notary essentially seen from the dimensions and fundamentalist, the notary must carry out thewith the Act, the code of conduct and prudential aspects, accuracy, honesty and trustworthy. If this aspect is neglected in deed, the Notary will bear the consequences for violations of the fundamental principles that must be met in his notary as an official secret has a position shall be kept and maintained by the Notary under the Act. Notary also bound by the same obligations, namely keeping the contents of the deed as provided in 16 subsection (1) f UUJN-Amendment No. 2 of 2014, which states that in the running position, the notary is obliged to everything regarding the deed he made and all information obtained to a deed in accordance with the oath / pledge of office, unless the law determines the other. In the explanation of the article said that the obligation to keep secret everything related to the certificates and other papers is to protect the interests of all parties associated with the deed. Article 322 paragraph (1) of the Criminal Code also states that the person who deliberately open secret that he is obligated to keep it because of the position or job, both current and former, shall be punished with imprisonment for nine (9) months or a fine of Rp. 600.- (six hundred rupiah). both present and former, shall be punished with imprisonment for nine (9) months or a fine of Rp. 600.- (six hundred rupiah). both present and former, shall be punished with imprisonment for nine (9) months or a fine of Rp. 600.- (six hundred rupiah).

Under the provisions of Act No. 2 of 2012, amendments to the Act No. 30 of 2004, there are at least three (3) elements that obtain legal protection:

1 . The evidence produced by the Notary regarding legal actions or events made law because the legislation requires to be made by or in the presence of a Notary or the legal acts or legal events are made for members of the public asked the notary to be made right evidences meet highest quality standards or the lowest accordance with the norms or advantage contained in Act No. 2 of 2014. evidence it should obtain legal protection both in court and out of court in accordance with the quality standards.

2. Members of the public who have the evidence produced by the Notary well signaled by the legislation in force, nor requested by members of the public. Since the early members of the public right to know the evidence which meets the highest quality standards and which meets the lowest quality in accordance with the norms or legal norms in force. Members of the public who have evidence of the highest quality 
standards and lowest quality standards should obtain legal protection either in court or out of court, according to its quality standards.

\section{Notary To Use Rights And Obligations Dissenter-Changes In Accordance Uujn Act No. 2 Of 2014}

Liabilities dissenter to do with restrictions throughout the notary examined by any agency that seeks to require a statement or description of a notary relating to the deed or ever made by or in the presence of the notary. Notary as occupational and professional confidence required to keep secrets about a deed made and information or statements of the parties gained in deed, unless the Law ordered to divulge information or statements and give it to those who request it.

Notaries have an obligation not to reject notary, but for the benefit of those who have confide to the notary, that notary by the parties were able to keep all information or statements of the parties had given before a notary who deals in deed. Thus part of the oath / pledge notary containing that notaries will keep the contents of the deed and the information obtained in the office of a notary and is associated with the Article 16 paragraph (1) letter $f$ UUJN amendment of Act No. 30 of 2004 regarding the post of notary. The obligation to maintain secrecy on information obtained from clients or attentio, confirmed that the notary is not only obliged to secrecy of the content of the deed, but also must keep all information or statements or information obtained relating to the deed in question.

\subsection{Weaknesses And Solutions Of Protection Law Notary In Running The Secret Of Liability Position.}

Notary is an office of trust. This implies that they yang stints trustworthy positions and their office as a notary office of trust, so that the office of a notary as positions of trust and people who run the office tasks can also believed that the two are mutually supportive. Therefore notary in the running of their office have an obligation conceal everything about the deed made and all information obtained for a deed in accordance with the oath / pledge of office, unless the law determines the other (Article 16 paragraph (1) letter f) Act No. 2 of 2014, amendments to the Act No. 30 of 2004, that all obligations to keep everything related to the certificates and other papers is to protect the interests of all parties associated with the word. Already a Notary obligation to maintain professional secrecy is due. How would the Notary will be referred to as a trust office. But it turns out that professional secrecy can be dismantled by the investigators through their arguments through the Criminal Code and other laws and regulations.

Well, this is where the problems are sometimes a weakness for notaries themselves, because their rules are mutually superimposed on each other, create their own notary violation of the article may be penalized as Article 85 UUJN No. 30 of 2004. However, in UUJN-change No. 2 of 2014 was removed on the sanctions the official secret. But by the investigating authorities often use the argument of the Criminal Code and the Criminal Procedure. Not to mention at the same time when the notary hard to do the call even after going through the process that applies on the level of MPD (Council of Regional Supervisor) to MKN (Honorary Council of Notaries) as a final agreement, the notary can not be summoned by the investigator to be called questioning regarding a deed has been made, but later investigators notary deed to call witnesses for questioning, is already happening through the dismantling of official secret witness the deed.

\section{Closing}


Volume 7 Issue 2, June 2020

Nationally Accredited Journal,

Decree No. B/4130/E5/E5.2.1/2019

\subsection{Conclusion}

Based on the discussion and analysis as presented in the previous chapters by using methodology that puts a deep observation of the literature literature, the conclusions in response to the concerns raised are as follows:

- Under the provisions of Act No. 2 of 2014, amendments to the Act No. 30 of 2004 Article 4 and Article 16 paragraph (1) letter $f$, that Notaries have the authority and obligation to keep professional secrecy regarding the Deed and any information obtained in the manufacture of Deeds and conceal the contents of the deed and he knew a good description of the past, present and future. The rules are not only regulated in UUJN, Criminal Procedure Code, and other rules governing confidentiality also remains on a deed.

- A Notary is not allowed to open the contents of (secret) deed he made as stipulated in Article 16 paragraph (1) letter (f) UUJN No. 2 of 2014 amendments to the Act No. 30 of 2004, that a Notary is obliged to confidentiality deed made and all information obtained in order to deed in accordance with the oath / pledge of office, unless the law determines the other. The exceptions where the notary is obliged to testify or reveal information that has been made in violation of the deed of secrecy provisions position. And notaries who open the contents of (secret) certificate from UUJN legal protection, organization and assembly supervisor Notary notary, a license to open the contents of (confidential) deed or give information he knows.

- Based on the descriptions that have been mentioned previously in the implementation of the legal protection of notary there are still weaknesses in terms of both the application and of the rule of law itself. Hope writer in the future will set up a legislation or regulation, where among the upholders of justice, as well as agencies or institutions other law more concerned about the interests of the wider community in the formation of legislation, so that between those seeking justice and law enforcement work, was able to create a good synergy in the interest and progress of a nation.

\subsection{Suggestion}

Conclusion Based on the above, the final section will discuss and give advice, as follows:

- It should be for all parties, investigators, prosecutors, and judges to respect, uphold the oath of office, official secret, and the right of refusal held by a notary and have always worked well together in terms of exchange of information and still adhere to their Code of Conduct in every profession, without exception Notary, effort and ongoing efforts are expected as part of efforts to enforce the law and is also expected to positively impact the future of law enforcement.

- Preferably in bearing witness to a case involving a notary to witness in a court, a notary can still hold fast to what is stated in the oath of office. And for that we need a legal guarantee set out in the form of legislation, if necessary, the state partly responsible and protect the notary.

\section{References}

[1] Kohar, A, 1984, Notaris Berkomunikasi. Alumni.Bandung

[2] Ngadino, 2019, Tugas dan tanggung jawab jabatan notaris di indonesia. UPT penerbitan universitas PGRI semarang. 


\section{JURNAL AKTA}

eISSN : 2581-2114, pISSN: 2406-9426

[3] Pengurus Pusat Ikatan Notaris Indonesia.2008, Jati Dori Notaris Indonesia, dulu, sekarang, dan di masa dating, Gramedia, Jakarta.

[4] Redaksi Lima Adi Sekawan (ed). 2006, Lengkap UUD 1945 (dalam Lintasan Amandemen) dan UUD (yang pernah berlaku) di Indonesia (sejak Tahun 1945). Lima Adi Sekawan, Jakarta.

[5] Soejono Soekamto, Pengantar Penelitian Hukum, UI Press, Jakarta,

[6] Act No. 2 of 2014 UUJN Revision of Act No. 30 of 2004 on the Rules of Notary (PJN) 